\title{
ANTOLOGIJE BIT I ANDERGRAUND POEZIJE VOJISLAVA DESPOTOVA**
}

Polazeći od šireg konteksta recepcije bit i andergraund poezije u našem kulturnom prostoru, u radu se analizira antologija Fuck you: iz američke underground poezije (1985, 1986, 1989, 1991, 1998) Vojislava Despotova. Na osnovu istraživanja došli smo do uvida da je Despotov ovu antologiju i njen predgovor preveo iz izdanja Fuck you: Underground poems. Untergrund Gedichte (1968) Ralf-Rajnera Rigule, iako je u knjizi navedeno da je on autor predgovora i priređivač. Bavićemo se relacijama ove dve knjige i njihovim kulturnim i političkim značajem i funkcijama. Takođe, osvrnućemo se i na antologiju Beat poezija koju je Despotov objavio 1991. godine, a koja takođe predstavlja prevod izbora Beat Poets koji je Džin Barou načinio 1961. Uporednom analizom i analizom prevoda i prevoda-plagijata nastojaćemo da osvetlimo problematiku u procesu recepcije, prepreke u usvajanju stranog i kreiranje odgovarajućeg konteksta, kao i ulogu posrednika i shvatanje antologije kao izvora.

Ključne reči: bit poezija, underground poezija, antologija, Vojislav Despotov, prevod, priređivač, plagijat, 1968. godina.

Vojislav Despotov (1950-2000), kao prevodilac, antologičar i pesnik ima značajnu ulogu u recepciji savremene američke poezije, pretežno bit i andergraund usmerenja. On je već 1974. godine u časopisu Polja (br. 189, novembar 1974) načinio kratak izbor „Bit poezija“", 1 u periodu od 1985. do 1998. godine objavio je pet izdanja pregleda Fuck you: iz američke underground poezije, od 1990. do 1991. izdavao je magazin za američku kulturu Hey Joe!, a 1991. priredio je izbor Beat poezija. Takođe, kad je reč o prozi bitnika, ključno mesto svakako ima roman $N a$ putu Džeka Keruaka (Kerouac, 1922-1969), koji je Despotov preveo 1988. godine i koji je

\footnotetext{
*sonja.veselinovic@ff.uns.ac.rs

** Rad je nastao u okviru projekta broj 178005, „Aspekti identiteta i njihovo oblikovanje u srpskoj književnosti”, koji finansira Ministarstvo prosvete, nauke i tehnološkog razvoja Republike Srbije.

1 Izbor se sastojao od pesama: Lorenc Ferlingeti „Prenaseljenost”, Pol Kerol, „Poklon puritancima”, Gregori Korso, „Sacré Coeur cafe”, Leroj Džons, „Odlazak sa Zapada” i Filip Valen, „Plus, minus”, Polja, br. 189, nov. 1974, str. 28. Prevodi su puni slobodnih izmena i intervencija, skraćivanja, grešaka u prevodu, a ne vodi se računa ni o obliku, dužini stiha i ritmu.
} 
objavila Književna zajednica Novog Sada, a tu je i Satori u Parizu dve godine kasnije (Krovovi, Sremski Karlovci i Studentski kulturni centar, Niš). Ova kultura prisutna je i u njegovom pesničkom, pripovedačkom i esejističkom opusu. Upravo iz šire perspektive Despotovljevog delovanja, ali i delovanja neoavangardne književne scene, zanima nas koncepcija i značaj njegovih pregleda andergraund i bit poezije.

Prvi izbor Fuck you: iz američke underground poezije Despotov je objavio 1985. u izdanju Književne zajednice Novog Sada. Sa potpuno crnim koricama, velikim belim slovima „Fuck you” u središtu gornje polovine korice i nešto sitnijim fontom ispisanog ostatka naslova $u$ donjem desnom uglu, knjižica (41 strana) je delovala vrlo upečatljivo i provokativno, iako ničeg andergraund, opskurnog niti prevratničkog nije bilo kod samog izdavača, uglednog i uticajnog, kao ni u činjenici da je knjiga objavljena u čak tri hiljade primeraka. ${ }^{2}$ Uz predgovor „Dvadeset godina underground-a, otprilike", pregled sadrži trinaest autora (dvanaest pesnika i jedna pesnikinja): Čarls Bukovski (Bukowski, 1920-1994), „Bezglasna briga plave ljubičice”, „Muški klozet”; Ted Berigen (Berrigan, 1934-1983), „Život sa Krisom”; Frenk O’Hara (O’Hara, 1926-1966), „Fantazija”, „Pesma”, „Pesma”; Lenor Kendel (Kandel, 1932-2009), „Strip”, „Ljubavna pesma”; Džon Viners (Wieners, 19342002), „Bar 'Orao”, „Pesma”; Aram Bojadžijen (Boyajian), „Dan kada sam se preobrazio u kineskog generala”, „Lusi, Nadžent, Huver, papa i Isus, svi zajedno u jednoj pesmi”, „Čovek koji je napisao najduži haiku na svetu”; Edvard Dorn (Dorn, 1929-1999), „Vakero”; Ed Sanders (Sanders, 1939), „Koka-kola tuš, „Banda pušačica”, „7”, „10”; Edvard Fild (Field, 1924), „Kura lepote”; Filip Vejlen (Whalen, 1923-2002), „I tako dalje”, „4:2:59 zadatak I”; Maks Finstin (Finstein, ${ }^{3}$ 1924-1982), „Neko drugo mesto”; Džek Spajser (Spicer, 1925-1965), „Ljubavna pesma 9”; Tuli Kapferberg (Kupferberg, 1923-2010), „Masturbirati je ljudski, jebati božanski”, „Točak sreće”, „Teorija gađenja”.

Ono što nas je posebno zainteresovalo za ovaj pregled andergraund poezije jeste neobičan izbor pesnika, pa i pesama, osobena postavka i redosled autora, kao i određene teze iz predgovora koje se ne uklapaju sasvim u dotadašnju recepciju bit, andergraund ili hipi poezije i kulture, odnosno kontrakulture. Recepcija bit poezije u skromnim okvirima započinje šezdesetih godina sa pokojim prevodom Alena Ginzberga (Ginsberg) i nastavlja se sedamdesetih, kada, recimo Ivana Jadrešić

\footnotetext{
${ }^{2}$ Radi poređenja, ista izdavačka kuća te godine naučne knjige (P. Milosavljević, A. Savić Rebac, E. Kasirer) štampala je u tiražu od 1000, 1500 ili 2000 primeraka, a domaće pesničke pretežno u 1000 primeraka. U ovako velikom tiražu poput Despotovljevog izbora objavljivani su npr. Gete, Hajdeger, Prop.

${ }^{3}$ U knjizi pogrešno piše ime u originalu kao Finstin.
} 
u časopisu Polja 1970. godine pravi temat „Sveti barbari: o američkoj kontrakulturi i još koječemu", u koji će uključiti Ginzberga, Džeka Keruaka, Majkla Meklura, Liroja Džonsa, Lorensa Ferlingetija, Gregorija Korsa i Džonatana Vilijamsa, ključne autore bita, a na istom tragu bio je i sam Despotov u svom izboru u istom časopisu četiri godine kasnije. Vladislav Bajac i Vojo Šindolić objavljuju pregled Pesnici bit generacije (K. Reksrot, L. Bruks, Dž. Keruak, L. Ferlingeti, A. Ginzberg, G. Snajder, K. Kizi, G. Korso, P. Orlovski, R. Hanter, M. Meklur) 1979. godine. No, pravi zamah u recepciji bitnika jesu osamdesete godine, kada su se u atmosferi većih političkih sloboda i širih kulturoloških potreba ostvarili uslovi za prihvatanje i prevođenje onoga što je viđeno kao kultura političkog bunta, seksualnih sloboda, alternativnih verovanja, otvorenosti prema opijatima. Osobito nakon Ginzbergove posete Jugoslaviji 1980. godine, bit pokret i Ginzberg kao njegova zvezda postaje zapravo, u paraleli sa rokenrol kulturom, jedna od mejnstrim opcija, tolerisana od strane establišmenta.

Despotov $\mathrm{u}$ ovom izboru predstavlja pesnike koji su rođeni kada i predstavnici prve generacije bitnika - ali ne same ključne predstavnike - kao i mlađu generaciju, takozvani post-bit (post-Beat). S obzirom na to da su i Vladislav Bajac i Vladimir Kopicl za svoju antologiju američke poezije Trip iz 1983. godine preuzeli izbor mlađe bit poezije iz serije New Directions 37: An International Anthology of Prose and Poetry iz 1978. (navedene kao izvor među drugim antologijama na kraju njihovog izbora), te da američka andergraund scena uglavnom nije bila poznata domaćim antologičarima iz prve ruke (mada je Despotov boravio u SAD), tragali smo za izvorom ili uzorom za Despotovljev odabir pesnika. Iako se u njegovom predgovoru pominje časopis Fuck you Eda Sandersa koji je izlazio 1962-1965. u Njujorku, ${ }^{4}$ kao ključna publikacija tzv. mimeo revolucije, malotiražnog, nekomercijalnog objavljivanja i umnožavanja putem mimeografa, on nije delovao kao realan izvor. Sandersova parola u časopisu bila je „Objaviću bilo šta”, naslovnica najčešće iscrtana istočnjačkim simbolima, prizorima seksa, polnih organa ili crtežima marihuane i drugih psihoaktivnih supstanci, a u tom pravcu su najčešće išli i literarni prilozi, mada je bilo i značajnog političkog aktivizma. Sanders i saradnici okupljeni oko časopisa i drugih publikacija predstavljali su drugu generaciju bita i povezivali starije autore sa hipi pokretom iz sredine šezdesetih godina. Pregledajući brojeve Sandersovog časopisa, ${ }^{5}$ ustanovili smo da se jedan deo autora iz Despotovljevog izbora redovno pojavljuje, ali čak ni tu nisu bile zastupljene pesme koje je on

\footnotetext{
${ }^{4}$ Up. Daniel Kane, All Poets Welcome: The Lower East Side Poetry Scene in the 1960s, University of California Press, 2003.

${ }^{5}$ http://realitystudio.org/bibliographic-bunker/fuck-you-press-archive/
} 
predstavio. I na osnovu niza drugih razloga delovalo je prilično neverovatno da je ovaj časopis koji je koncipirao, štampao i "distribuirao" jedan čovek mogao uistinu biti izvor.

Na osnovu prethodno uočenih poklapanja u recepciji bit poezije u Nemačkoj i Jugoslaviji, odnosno mogućnosti nemačkog literarnog posredništva u ovoj recepciji, ali i Despotovljeve upućenosti na nemačku kulturu kao prevodioca sa nemačkog, naišli smo na antologiju istog naziva, Fuck you: Underground poems. Untergrund Gedichte, objavljenu u Darmštatu 1968. godine, koju je uredio Ralf-Rajner Rigula (Ralf-Rainer Rygulla). Ova antologija imala je i drugo izdanje 1980. godine, koje je realnije moglo poslužiti Despotovu kao izvor. Rigulin dvojezični Fuck you sastoji se iz sledećih ostvarenja: T. Berrigan, „Leben mit Chris”, „Marthas Millionen”; P. Whalen, „Auf Weiteres”, „Aufnahme Nr. 4,15: VIII: 57, für N”, „4:2:59 Aufnahme I”; T. Kupferberg, „Theorie des Ekels”, „Das Glücksrad”, „Gedicht”, „Masturbieren ist menschlich... ficken göttlich”, „Bajonett Drill”; A. Saroyan, Aus: „Werke”; E. Dorn, „Vaquero”, „Das Lied ist aus für Nellie L.”; Ch. Bukowski, „Die lautlose Besorgnis eines blauen Veilchens”, „Männer-Klo”, „Natur-Gedicht”; J. Spicer, Aus: „Ding Sprache”, Aus: „Homage für Creeley”; F. O’Hara, „Phantasie”, „Gedicht”, „Gedicht”; L. Kandel, „COMICS”, „Liebe mitten in der Luft”, „Liebes-Gedicht”; E. Sanders, „Die Abkau-Bande”, „7”, „10”, „15”, „Coca-Cola Spülung”; M. Finstein, „ein anderer ort”, „wie einer von der truppe”; E. Field, „Klein Gwendolyn und die Gräfin”, „Schönheits-Kur”, „Reisen-Pazifik-Tintenfisch”; J. Wieners, „Die Adler Bar”, „Gedicht”; A. Boyajian, „Der Tag an dem ich mich in einen chinesischen General verwandelte”, „Lusi, Nugent, Hoover, der Papst und Jesus Christus alle zusammen in einem Gedicht”, „Der Mann der den längsten Haiku der Welt schrieb”. Kod Rigule autori su hronološki poređani, a evidentno je da je Despotov preveo svoju antologiju iz ovog izbora, izuzevši nekoliko pesama i Arama Sarojana. Iz Rigulinih napomena možemo videti da su pesme, osim kod nekoliko autora gde su uzete iz zbirki, zaista preuzimane iz nezavisnih, andergraund časopisa kao što su Fuck you, Intrepid i Entrails.

Pre nego što se posvetimo Rigulinom i Despotovljevom pratećem tekstu, trebalo bi sagledati kontekst u kojem se nemačka antologija pojavljuje te turbulentne 1968. godine. Pre ove antologije pojavili su se izbori Junge amerikanische Lyrik 1961. godine, poetički nešto šire koncipirana antologija koju su priredili američki pesnik Gregori Korso (Gregory Corso), i pisac, kritičar i urednik Valter Helerer (Walter Höllerer), potekao iz "Gruppe 47”; Beat: Eine Anthologie iz 1962. godine, koju je priredio novinar i publicista Karl Otto Paetel, kao i brošura Underground poems. Untergrund Gedichte. Letzte amerikanische Lyrik, koju je Rigula objavio 1967. Rigulina antologija Fuck you imala je znatno slabiju recepciju i značaj, 
međutim, od one koje će uslediti godinu kasnije i biti njome praktično najavljena (Müller-Dannhausen, 2011: 54) - ACID: Neue amerikanische Szene (Darmštat 1969. i 1975), koju je Rigula priredio sa Rolfom Diterom Brinkmanom (Rolf D. Brinkmann, 1940-1975), piscem i prevodiocem koji je mnogo doprineo recepciji angloameričke poezije u Nemačkoj i čije čitavo delo se kreće u ,kodovima studentskog pokreta" (Clare, 2016: 61). Brinkman je iste godine objavio i antologiju Silverscreen. Neue amerikanische Lyrik u Kelnu. U svojoj knjizi Slika i uticaj Amerike u nemačkoj poeziji od 1945. godine Gregori Dajvers o antologiji Fuck you piše:

Rigula sledi pristup sličan onom kod njegovih prethodnika, i pri uvođenju novih pisaca i pri upoznavanju nemačkih čitalaca sa skorašnjim kulturnim trendovima u Americi. Glavna razlika, međutim, jeste upadljivo apolitičan uređivački stav. Ovde ne nalazimo "drugu" Ameriku pesnika iz Lovenfelsove antologije Gde je Vijetnam?, onih čiji aktivizam i nesaglasnost odražavaju ideale i odgovornosti povezane sa participativnom demokratijom. Umesto toga, naglasak je na jednoj Americi naizgled lišenoj odgovornosti. Rigula promoviše ovaj američki kontrakulturni pohod kao potpunu negaciju društvenih vrednosti, sa naglaskom na njegovim anarhističkim crtama, pre nego crtama ma kojeg političkog izma. Njegov pogovor upućuje na elemente političkog protesta, ali predstavlja modus neslaganja koji krši prihvaćene norme bezočnom upotrebom opscenosti.

Kao što se vidi u naslovu, Rigulin izbor pesama agresivno se suočava sa čitateljem. Dok uvredljiv ton obeležava ostvarenja kao što su „Muški klozet” Č. Bukovskog, „Vežbe s bajonetom” T. Kupferberga i “Koka-Kola tuš” E. Sandersa, ostale su - a osobito pesme Teda Berigana, Edvarda Dorna, Frenka O’Hare, Džeka Spajsera i Filipa Vejlena - jednostavno dovitljive ili humoristične, andergraund u smislu antiliterarnog. Sandersov poziv na ,totalni napad na kulturu” karakteriše cilj ove radikalne grupacije pesnika, a ta rečenica takođe uspostavlja ton za ACID (1969), antologiju ne samo pesama, već i kratkih priča, eseja, manifesta, intervjua, stripova i fotografija. Za razliku od Fuck you, ACID je privukao dosta pažnje u štampi Zapadne Nemačke; štaviše, ponovljena izdanja pokazuju da se drži za glavni izvor kod nemačkih poklonika andergraund scene (Divers, 2002: 125-126).

Ako je Rigulina antologija delovala apolitično u Nemačkoj 1968. godine, koliko je izbor pesama preuzet iz nje mogao biti kontroverzan ili provokativan u Jugoslaviji 1985. godine? Isto toliko su adekvatne za predstavljanje ove poezije sa distancom od dvadesetak godina mogle biti i Riguline teze koje je Despotov preuzeo, odnosno doslovno preveo, ponešto izbacio i uveo nekoliko rečenica da kontekstualizuje predgovor u okviru datog trenutka, ne navodeći ipak nigde svoj izvor tj. originalni tekst. Njegov predgovor započinje rečenicom: „Betmen, super-čovek- 
super-slepi miš napušta SAD i u svom super-tenku bori se u Vijetnamu protiv superzla” (Despotov, 1985: 5), što je kod Rigule tek drugi deo rečenice („Batman hat Gotham City verlassen und kämpft in Vietnam in seinem Super-Super-Tank gegen das Böse” (Rygulla, 1980: 115)), u kojoj se izdvajaju parole „BURN, BABY, BURN" i "KILL KILL KILL FOR PEACE” i podignutom retorikom privlači pažnja, što je očekivano kod ovakvih tekstova koji uzmiču od uobičajenog kritičkog pristupa. Despotov potom pokušava da kontekstualizuje ovaj specifičan diskurs, pitajući se šta se događalo u Americi, „najzapadnijem društvu Zapada”, pre dvadesetak godina. Iz Rigulinog teksta izbaciće neke rečenice koje se odnose na film i one u kojima je očigledno odraženo vreme u kojem su pisane. Uporedimo tekstove s početka:

Der von Ed Sanders geforderte „totale Angriff auf die Kultur” kann nicht durch systemimmanente Kritik erfolgen, sondern durch Kritik von außen, d. h. von Kriminellen, Süchtigen und Farbigen. Ihre Slogans heißen: FICKT FÜR DEN FRIEDEN - KASTRIERT LBJ - NIMM LSD - VERLASS DIE SCHULE RONALD REAGAN IST LESBISCH.

Das totale Negieren aller Werte der Gesellschaft ergibt einen Lebenswandel, für den Begriffe wie Ordnung, sozialer Aufstieg, Sauberkeit, Bildung überhaupt nicht existieren. Die Leute vom Underground haben erkannt, daß innerhalb der Legalität nichts mehr verändert werden kann. Die massive Vergesellschaftung und das daraus resultierende Konformitätsverhalten wird mit einer extrem individualistischen Haltung beantvortet, die anti-Konsum und antizivilisatorisch ist.

Der Abscheu, den man vor dem Super-Kommerzialismus und Perfektionismus empfindet, drückt sich schon in der From der Publikationsmittel aus, in denen die Autoren des Underground veröffentlichen. (Rygulla, 1980: 115)

„Totalni napad na kulturu”, zahtevan od pesnika Eda Sandersa, ne može da rezultira kroz kritiku koja je imanentna sistemu već samo kroz tzv. kritiku od spolja, onu koja potiče od strane kriminalaca, bolesnika i obojenog življa.

Njihovi slogani bili su: jebi za mir - kastriraj lindona džonsona - uzimaj LSD napusti školu - ronald regan je lezbejka, itd. Ljudi iz podzemlja shvataju da se u okviru legaliteta ništa ne može promeniti odnosno da je bitna životna promena moguća samo totalnim negiranjem svih vrednosti. Odvratnost koja se oseća prema super-komercijalizaciji i perfekcionizmu ogleda se već i u samim formama publikacija koje pokreću autori underground-a. (Despotov, 1985: 5-6)

Na osnovu ovog odlomka vidimo da Despotov dosledno prevodi Rigulin tekst, a izbacuje jednu rečenicu, u kojoj bi „sveopšta socijalizacija” na koju se odgovara krajnje individualističkim stavom mogla biti negativno shvaćena, ali u kojoj se pojavljuje i reč anticivilizacijski, koju nalazimo u još jednoj Rigulinoj rečenici koju 
Despotov preskače: „Schon in der Beat-Bewegung zeigte sich das anti-zivilisatorische $\&$ anti-amerikanische Element" (Rygulla, 1980: 118). Dakle, čak i sedamnaest godina nakon Rigulinog teksta koji je ocenjen apolitičnim u kontekstu revolucionarne 1968. godine, nereda na Frankfurtskom sajmu knjiga, ${ }^{6}$ protesta protiv neokolonijalizma i pobune protiv domaće (nemačke) autoritarnosti, odnosno potrebe za alternativnim istinama i znanjima, koje mogu biti oličene u kontrakulturi, Despotov izostavlja one delove koji bi eventualno ukidali vremensko-prostornu distancu, čime se ova poezija i njene postavke predstavljaju kao udaljeni, američki fenomen, sa čijim se političkim premisama ne povlači nikakva paralela. $\mathrm{O}$ tome govori i poslednji pasus pogovora, $\mathrm{u}$ kojem je Despotov preveo početak Riguline rečenice o tome da je andergraund fenomen specifičan za $\mathrm{SAD}$, ali je izbegao da prenese da je uslovljen upravo „potpuno usavršenim i samo-regulišućim društvom” (Rygulla, 1980: 120), nego je to tako zato što je ,tamo perfekcionisan i, naravno, sankcionisan. Bez obzira da li pesnici iz ovog skromnog izbora danas pevaju i misle drugačije, njihova moralna snaga kao kritičara sopstvene životne scene ostaje da živi za istorijsku savest i značajan dokument o kritičnom punktu pluralizma dvadesetog veka" (Despotov, 1985: 8). Opet se naglašava distanca i neprimenjivost datog modela razmišljanja na domaću situaciju - koji svakako nisu karakterisali nemačku recepciju kontrakulture kao što se u suštini potencira provokativnost jezika i seksualnosti i opscenosti kao najčešćih tema, nad eventualnim političkim aktivizmom.

Zanimljivo je da Despotov u predgovor nije ubacio čak ni neke zanimljivosti koje su mu možda mogle biti poznate, kao recimo to da se Tali Kapferberg (koji nema nikakvu recepciju kod nas docnije) pojavljuje u filmu Misterije organizma (1971) Dušana Makavejeva, koji se bavi sudbinom austrijsko-američkog psihijatra Vilhelma Rajha (Reich), ali zato prenosi Riguline reči o značaju Rajhovih teza o seksualnosti za američki andergraund. To ne dopunjava ni u docnijim izdanjima svoje antologije, kada je film Makavejeva već bio oslobođen zabrane prikazivanja. Despotov je antologiju Fuck you proširivao novim pesnicima ili pesmama više puta: u izdanju iz 1986. dodao je po jednu pesmu Boba Kaufmana (Kaufman, 1925-1986; „Heter Bel”) i Lorensa Ferlingetija (Ferlinghetti, 1919; „Prenaseljenost”), a u znatno obimnijem izdanju iz 1989. pojavljuju se Ginzberg („Dupeljub”, „Molim te maestro”, „Park Grant”), Harold Nors (Norse, 1916-2009; „Zbog dupeta tvog imam nesanicu”, „Ameriku viđam svakodnevno”, „Bio je to običan dan u pomrčini”), Džek Keruak („Drmni mi krasuljak”, „231-i napev”), Gregori Korso („Pesnici stopiraju na autoputu”), Robert Krili (Creeley, 1926-2005; „Znam čoveka”), Pol Kerol (Carroll,

6 Up. Wolfgang Kraushaar, Frankfurter Schule und Studentenbewegung: von der Flaschenpost zum Molotowcocktail, Vol. 1, Hamburg: Rogner\&Bernhard, 1998. 
1926-1996; „Poklon puritancima”, „Otac”), Liroj Džons (Jones/Amiri Baraka, 19342014; „Odlazak sa Zapada”), Anselm Holo (Hollo, 1934-2013; „Istinita priča o otkriću LSD-ija”), En Voldmen (Waldman, 1945; „Pritisak”) i Džonatan Vilijems (Williams, 1929-2008; „Kad bi moć mogla”), i dodato je nekoliko pesama Bukovskog, O'Hare, Kapferberga, Vejlena, Kaufmana i Dorna. Neke od ovih pesama bile su zastupljene i u Despotovljevoj antologiji Beat poezija dve godine kasnije. Četvrto i peto izdanje Fuck you $(1991,1998)$ isto je kao treće.

Od prvog izdanja Fuck you V. Despotova, naznačeno je da ,izbor i prevod s engleskog" načinio sam Despotov, a u kasnijim izdanjima nakon predgovora, osim potpisa, čak stoji i „N. Sad, 1983”. U trećem izdanju stoji i napomena:

Izvesnoj istorijskoj razdaljini, pomenutoj u predgovoru uz prvo izdanje, pridodato je još pet godina. Uspehu ove knjige, prodaji i čitanju - što je mogućnost da se andergraund legalizuje kao deo ovdašnje kulture - najviše su doprineli sami pesnički tekstovi; u trećem izdanju ih je znatno više zato što su vidici prošireni FUCK YOU je počeo da obraća pažnju i na drugu poeziju koja se pisala u vreme najžešćeg andergraunda $\mathrm{i}$ to najviše zbog očiglednog uticaja i međusobnog trpljenja. U Novom Sadu, 14.12.1988. (Despotov, 1989: 9).

Prisvajanje Rigulinog izbora nije toliko iznenađujuće, mada se ne može govoriti o nedostatku izvora, originalnih zbirki ili antologija, kada pogledamo spisak antologija na koje kao izvore upućuju Bajac i Kopicl na kraju svog Trip-a. No, preuzimanje njegovog pogovora kao vlastitog teksta možemo posmatrati samo kao plagiranje, a čini se neobjašnjivim, pošto je Despotov u to vreme pisao eseje koji su se bavili upravo vezom književnosti i društvenih fenomena, ${ }^{7}$ štaviše, njegov esej „Antireganoezija” iz knjige Vruć pas (1985) predočava upravo nove umetničke (andergraund) prakse u SAD, sa osvrtom na bitnike kao prethodnike.

A kad je reč o „legalizovanju” andergraunda - što je apsurd po sebi - sam tiraž ovih antologija, kod uglednog izdavača, pokazuje kako one nisu ni u jednom trenutku smatrane problematičnom kontrakulturom, a osobito groteskno deluje spisak sponzora (market, restoran, knjižara, vulkanizer) u izdanju iz 1989. (tiraž 2500), uz spisak građana pod napomenom „Oni su pomogli štampanje ove knjige”, među kojima ima i istaknutih književnika i univerzitetskih profesora. U svom tekstu o antologiji, pod naslovom „Zbornik opreke”, Vladimir Kopicl (inače jedan od recenzenata Fuck you-a; drugi je sam Despotov) piše kako je Despotov izabrao i dobro preveo vanserijske, relevantne pesme, dok je „uvodni esejistički sažetak najbitnijih eksternih i drugih odrednica govora kome pripadaju i koji ostvaruju valjan

\footnotetext{
${ }^{7}$ Up. knjigu Vruć pas (Matica srpska, 1985), kao i eseje iz ciklusa "Konac dvadesetog veka" objavljivane u Letopisu Matice srpske u periodu 1982-1985.
} 
prilog njihovom potpunijem razumevanju" (Kopicl, 2000: 87). U nekim drugim rečenicama Kopiclovi utisci kao da nisu baš nedvosmisleno pozitivni, već ostavljaju prostora i za drugačije zaključke na osnovu izloženog:

Ovakav postupak pri izboru pokazuje se ne samo kao zalog njegove osobenosti već i kao dragocenost, jer ako su se u zadatom kontekstu i morali očekivati tekstovi Čarlsa Bukovskog i Edvarda Filda, pravo je iznenađenje i zadovoljstvo u njemu otkriti uključene primere tekstualnog angažmana velikana poput Frenka O’Hare ili Teda Berigena čiji su poetski interesi jugoslovenskim čitaocima do sada predstavljani obično u nešto drugačijem svetlu. ${ }^{8}$ (Kopicl, 2000: 86)

I antologija Beat poezija (1991), objavljena kao treća knjiga u novosadskoj izdavačkoj kući Četvrti talas koju je Despotov pokrenuo, u okviru edicije „Dead Poets Society", a reklamirana i kao vanredni broj pesnikovog privatnog časopisa za američku kulturu Hey Joe u samom časopisu, takođe je preuzet izbor Džina Baroa ${ }^{9}$ Beat Poets (London, 1961). Doduše, u njoj ne piše da je Despotov načinio izbor, već samo da je preveo sa engleskog, ali nije naveden ni naslov izvornog, originalnog dela. Očigledno je da za Despotova antologija nije predstavljala autorsko delo, u koje je uložen trud i znanje. Beat poezija sadrži sledeće autore: P. Kerol (,Spokojan život: bokal, sunce i plantaža avokada”, „Poklon puritancima iz indijanske prodavnice duvana”, „Otac”), G. Korso („Pesnici stopiraju na autoputu”, „The Sacre-coeur cafe”, „Jednu godinu dalje”), E. Dorn („Sudbina nenajavljenih godina”, „Kada homići”), L. Ferlingeti („Daleko iznad”, „Stalno rizikujući”), A. Ginzberg („Iza stvarnosti”, „Na Apolinerovom grobu”, „Odgovor”), L. Džons („Odlazak sa Zapada”), Dž. Keruak („Spis o zlatnoj večnosti”, „231-i napev”), R. Levinson („Utišanost pesme”), M. Meklur („Kanu: eksplikacija”, „Logos: čvor”), G. Snajder („,Tragovi pare”, „Dolina reke Nuksak”), F. Vejlen (,Plus ca change”, „Ljubavno zbogom za Čikago reviju”), Dž. Viners (,Pesma za muzej Goers”), Dž. Vilijems (,Kad bi noć mogla da ustane i prošeta", „Neko to mora iza brda”).

U ovoj knjizi je bar uz predgovor potpisan njegov autor, a to je i jedan vrlo koristan predgovor, s obzirom na to da je među vrlo retkim u ranoj recepciji bita koji ne govori o biografijama pesnika ili o bitu kao društvenom fenomenu, već upravo o stilskim, formalnim $\mathrm{i}$ tematskim specifičnostima $\mathrm{i}$ odnosu prema tradiciji. Baroov izbor okuplja brojne pesme visoke estetske vrednosti, za razliku od mnogih prisutnih

\footnotetext{
${ }^{8}$ Osim Beriganove pesme „Život sa Krisom”, teško da bi se ostale mogle dovesti u vezu sa angažovanim pesništvom.

9 Eugene Baroff (1924-1982), američki organizator umetničkih izložbi, pisac, predavač, živeo i radio u SAD i širom Evrope; 1968. godine koncipirao izložbu "Engleska i američka savremena grafika" u Muzeju savremene umetnosti u Beogradu.
} 
u Fuck you antologiji, odabranih u drugom ključu. Nažalost, bez posredovanja nemačkog prevoda, ovde je Despotovljev prevod nesigurniji i greške su prisutnije, kako u nespretnim formulacijama u predgovoru, tako i u samim pesmama. Kerolova pesma „Still Life: Tankard, Sun, and Avocado Plant” postaje „Spokojan život: bokal, sunca i plantaža avokada" umesto mrtva priroda i biljka avokada, dok u istoj pesmi „Even that oil you did of me in freak-show barker's gaudy vest” postaje „Čak i to ulje koje si bacio na mene, obučenog u jaknu nakinđurenog čudovišta”, „Of women whose cells of blood were attics with a burnt-out moon” prevedeno je kao „Žene čija su krvna zrnca bila puna iscrpljenog meseca”, a u pesmi „Otac” istog autora „cocky kid” je „kurati dečak”, „Stuck somewhere in the dresser drawer” prevodi se kao „iščeprkana negde u fioci stočića”, a „Hair, bone, brains \& cock \& skin rotten in the earth these 16 years” kao „Kosa, kost, mozak, kita i koža rđaju u zemlji ovih 16 godina". Slični problemi nastavljaju se kroz čitavo izdanje, tako da mnoštvo pesama deluje konfuzno i njihov kvalitet ne može doći do izražaja.

Zanimljivo je kako slika sa kraja dvadesetog veka odražava jezičkokulturno stanje iz devetnaestog veka na prostoru Vojvodine. Nemački jezik u slučaju Despotovljevog prevoda poslužio je opet kao jezik posrednik između naše i neke druge kulture, ali antologija koju je on preveo bila je u Nemačkoj jedna među mnogima u ranoj recepciji i dala sebi slobodu da se bavi jednim aspektom ove književne scene, seksualnim slobodama i prkosom građanskom vaspitanju. S obzirom na prilično zakasnelu recepciju bita/post-bita kod nas, apolitičnost ovog izbora možda nije jedan od najvećih problema, mada jeste upadljiva. Veći problem jeste slaba estetska vrednost gotovo polovine pesama, što u kombinaciji sa provokativnom seksualnom tematikom ponegde više naginje pornografiji nego književnosti. Nesumnjivo, nezaobilazan je značaj otvorene tematizacije homoseksualnosti i ovde i u prevodima Ginzberga (osobito eksplicitno u knjizi Urlik uma iz 1983) za našu kulturu kao doprinos toleranciji. Međutim, u književnom konekstu Fuck you u više pogleda daje pogrešnu sliku onoga što predstavlja: najpre, kao plagijat, nudi nešto što je načinjeno na drugom mestu i u drugo vreme, za drugu publiku, kao autentično delo; zatim jedan provokativan kontrakulturni projekat sa, kako ističe Dajvers, „uvredljivim” naslovom koji neposredno uključuje čitaoca, donosi u okviru ugledne izdavačke kuće sa velikim tiražem, te govori o "legalizovanju andergraunda", što sve deluje kao konformizam i podvala i u potpunoj je suprotnosti sa izvornim načinom objavljivanja datih tekstova; i naposletku, pružajući sveden tematski okvir (naglasak na seksualnoj revoluciji) i slabe pesme u ovoj knjizi i loše prevode izvrsnih pesama u knjizi Beat poezija utiče i na sužena razumevanja značaja bit i post-bit poezije uopšte, koja su u našoj prevodnoj književnosti prisutna. Recimo, zbog prenaglašavanja izvanredne i revolucionarne pozicije bitnika često se previđa njihova pozicija na liniji 
američke književnosti koja vodi od V. Vitmana, V. K. Vilijamsa i E. Paunda, do savremenih pesnika. Plagijat kao činjenica prevodne književnosti svakako da ne može biti ništa pozitivno, ali je vrlo indikativno i ne sme se zaobići u sagledavanju odnosa prema autorstvu antologije kao književnog dela. Odnos prema čitaocu koji se očituje Despotovljevim prevođenjem tuđeg predgovora i predstavljanjem kao vlastitog, krajnje je porazan i nazadan, te unosi i neke drugačije tonove $u$ vrednovanje neoavangardnog koncepta, emancipaciju čitaoca, angažman i mit o neshvaćenosti.

Sonja V. Veselinović

\section{ANTHOLOGIES OF BEAT AND UNDERGROUND POETRY EDITED BY VOJISLAV DESPOTOV}

\section{Summary}

In the context of Serbian (Yugoslavian) translations and literary reception of the Beat and post-Beat generation of poets, the anthology Fuck You: from the American Underground Poetry (Fuck you: iz američke underground poezije; 1985, 1986, 1989, 1991, 1998), edited by the neo-avant-garde poet, novelist and translator Vojislav Despotov, seems slightly incongruous and peculiar in its selection of poets and poems and its foreword. For that reason, I searched for a potential source of Despotov's anthology and found it in the German anthology Fuck you: Underground poems. Untergrund Gedichte (1968, 1980), edited by Ralf-Rainer Rygulla. Namely, Despotov translated Rygulla's anthology and his afterword almost completely and without referring to any sources, claiming the authorship of the selection, the translation from English and the accompanying text. Rygulla's selection and the afterword had been perceived as apolitical in his native culture in the framework of the revolutionary year 1968 and among other, more socially and politically engaged anthologies of contemporary American poetry. However, Despotov made it even less relevant in this regard, transposing it eighteen years after its initial publication. The other anthology that Despotov published in 1991, Beat Poetry (Bit poezija) is also not an original, it is entirely based on Beat Poets edited by Gene Baro in 1961; this time, however, Despotov did not appropriate Baro's foreword, crediting him properly instead. Apart from plagiarizing someone else's selection of poets and poems, the problem with this anthology is very poor translation from English, which underlines the importance of German as mediatory language in the previous case. For all that, the contribution of these anthologies to the reception of Beat and post-Beat poetry is rather questionable, counterproductive and disadvantageous.

Keywords: beat poetry, underground poetry, anthology, Vojislav Despotov, translation, editor, plagiarism, the year of 1968 . 


\section{LITERATURA}

Bajac, V.-Kopicl, V. (prir.) (1993). Trip: vodič kroz savremenu američku poeziju. Beograd: Narodna knjiga.

Baro, Gene (ed.) (1961). Beat Poets. London: Vista Books.

Clare, J. (2016). Protexte. Interaktionen von literarischen Schreibprozessen und politischer Opposition um 1968. Bielefeld: Transcript Verlag.

Despotov, V. (prir.) (1974, novembar). Bit poezija. Polja, br. 189, 28.

Despotov, V. (prir.) (1985). Fuck you: iz američke underground poezije. Novi Sad: Književna zajednica Novog Sada.

Despotov, V. (1985a). Vruć pas. Novi Sad: Matica srpska. (Štampano ćirilicom!)

Despotov, V. (prir.) (1986). Fuck you: iz američke underground poezije. Novi Sad: Književna zajednica Novog Sada.

Despotov, V. (prir.) (1989). Fuck you: iz američke underground poezije. Novi Sad: Književna zajednica Novog Sada.

Despotov, V. (prir.) (1991). Beat poezija. Novi Sad: Četvrti talas.

Despotov, V. (2012). Konac dvadesetog veka. Novi Sad: Misao.

Divers, G. (2002). The Image and Influence of America in German Poetry Since 1945. Rochester: Camden House.

Kane, Daniel (2003). All Poets Welcome: The Lower East Side Poetry Scene in the 1960s, Berkeley and Los Angeles, London: University of California Press.

Kraushaar, W. (1998). Frankfurter Schule und Studentenbewegung: von der Flaschenpost zum Molotowcocktail, Vol. 1. Hamburg: Rogner\&Bernhard.

Kopicl, V. (2000). Zbornik opreke. Pantić, M. (ur.) (2000). Vojislav Despotov: uspomena na dugo sećanje. Novi Sad: Centar za političko obrazovanje. 8687.

Müller-Dannhausen, L. (2011). Zwischen Pop und Politik: Elfriede Jelineks intertextuelle Poetik in "wir sind lockvögel baby!". Berlin: Frank \& Timme $\mathrm{GmbH}$.

Rygulla, R.-R. (Hrsg.) (1980). Fuck you: Untergrund Gedichte. Frankfurt am Main: Fischer Taschenbuch Verlag. 